\title{
Performance of Strawberry (Fragaria $x$ ananassa Duch.) Varieties for Growth and Fruit Physical Parameters under Western Malwa Plateau Conditions of Madhya Pradesh, India
}

\author{
Umesh Kumar*, Priyamvada Sonkar and Pankaj Maida
}

Department of fruit science, KNK College of Horticulture Mandsaur (M.P.) 458001, India

*Corresponding author

\section{A B S T R A C T}

\section{Keywords}

Strawberry, Different varieties like Chandler, Sweet Charlie, Tioga and Pajaro, Specific gravity, Fruit shape and Number of Crowns

Article Info

Accepted:

15 December 2019

Available Online:

20 January 2020
A research trial was carried out in the experimental field of Department of fruit science, KNK College of Horticulture Mandsaur Madhya Pradesh during the year 2017-2018 to evaluate some strawberry varieties in sub-tropical region (Wastern Malwa Plateau condition) of Madhya Pradesh. The runners of 12 strawberry varieties i.e., viz. $\mathrm{V}_{1}$ (Northwest), $\mathrm{V}_{2}$ (Tioga), $\mathrm{V}_{3}$ (Pajaro), $\mathrm{V}_{4}$ (Seascape), $\mathrm{V}_{5}$ (Fern), $\mathrm{V}_{6}$ (Chandler), $\mathrm{V}_{7}$ (Shimla Delicious), $\mathrm{V}_{8}$ (No.5), $\mathrm{V}_{9}$ (Dil Pasand), $\mathrm{V}_{10}$ (Larson), $\mathrm{V}_{11}$ (Torrey) and $\mathrm{V}_{12}$ (Sweet Charlie) were planted at $30 \times 30 \mathrm{~cm}$ apart on the ridge beds at end of October. The design of experiment was Randomized block design (RBD). The results of the study indicated that out of the varieties tried, the strawberry variety $\mathrm{V}_{6}$ (Chandler) proved to be the best in producing maximum plant height $(14.27 \mathrm{~cm})$, Number of leaves per plant (18.07) except the number of crown's per plant. The number of crown(s) per plant was recorded in variety $\mathrm{V}_{10}$ (Larson) 2.43. Maximum fruit diameter $(2.47 \mathrm{~cm})$, fruit weight $(8.58 \mathrm{~g})$, fruit volume $(8.23 \mathrm{ml})$ were found in variety $\mathrm{V}_{6}$ (Chandler) whereas fruit length $(3.80 \mathrm{~cm})$ observed in variety $\mathrm{V}_{10}$ (Larson). Best specific gravity was recorded in variety $\mathrm{V}_{11}$ (Torrey). Fruit full maturity after fruit set (31.11 days) were found in variety $\mathrm{V}_{2}$ (Tioga).Based on the experimental findings it was concluded that variety $\mathrm{V}_{6}$ (Chandler) be recommended as best variety under the Wastern Malwa Plateau condition of Madhya Pradesh.

\section{Introduction}

Strawberry (Fragaria $x$ ananassa Duch.) is an important fruit of family Rosaceae and occupies an important place among the small fruits.It is an aggregate fruit and octapoloid in nature having basic chromosome number $2 \mathrm{n}=$ $8 \mathrm{x}=56$ (Singh et al., 2016). Strawberry is one of the important fruit crops of temperate region. It is also grown to a limited extent in subtropical areas (Kumar and Kumar, 2011).
There is a considerable variation among different strawberry varieties for their adaptability in a particular set of agro-climatic conditions (Sharma et al., 2014). It is very much liked for its cool and refreshing nature. Fruits are of high demand for fresh market and for processing industries. The other important advantage of strawberry cultivation as gives early and high returns from a unit area. Yield and fruit quality of strawberry is influenced by a number of factors like 
growing environment, soil condition and cultivars (Kumar, A. and Kumar, P. 2011). The research work for finding suitable varieties has however, been limited to subtropical regions (Wastern Malwa Plateau condition) of Madhya Pradesh. Therefore, the present investigation was planned with the objective to assess the performance of 12 different strawberry varieties in district Mandsaur of Madhya Pradesh.

Strawberry is eaten as fresh and highly used in processing industry for making various products. Fruit colour, texture, odour and the balance between sweetness and sourness have been identified as important determinants of overall quality of strawberry fruit (Shamaila et al., 1992).

\section{Materials and Methods}

The present investigation was laid out in RBD with 12 varieties as treatments and three replications during the year 2017-2018 at the Instructional cum Research Fruit Orchard, Department of Fruit Science, K.N.K. College of Horticulture, Mandsaur (M.P.).Runners of 12 strawberry varieties i.e., viz. $\mathrm{V}_{1}$ (Northwest), $\mathrm{V}_{2}$ (Tioga), $\mathrm{V}_{3}$ (Pajaro), $\mathrm{V}_{4}$ (Seascape), $\mathrm{V}_{5}$ (Fern), $\mathrm{V}_{6}$ (Chandler), $\mathrm{V}_{7}$ (Shimla Delicious), $\mathrm{V}_{8} \quad$ (No.5), $\mathrm{V}_{9}$ (Dil Pasand), $\mathrm{V}_{10}$ (Larson), $\mathrm{V}_{11}$ (Torrey) and $\mathrm{V}_{12}$ (Sweet Charlie). The runner were procured from Veer Chandra Singh Gadwali Uttarakhand Horticulture and Forestry University Bharsar Podi Gadwal and acclimatized for a day. The soil of the experiment plot was well prepared by repeated ploughing followed by planking to obtain a fine tilth. The soil ploughed 2-3 times by soil turning, plough, harrowed, leveled and the weeds were rooted out. The well rooted runners of uniform size were transplanted on well prepared raised beds. Runners of strawberry having 2-3 full open leaves were transplanted randomly at the spacing $30 \mathrm{~cm} \mathrm{x}$ $30 \mathrm{~cm}$ in the experimental plots. Healthy and sound runners were selected for planting. Runners were placed in the receiving medium to a depth so that the crown remained exposed but the roots were all buried. Once in place, the soil around the plant was packed and patted firm, down, around the base of the stem. After planting the plants were irrigated immediately. Various post planting operations were done which mainly include spraying of nutrients, irrigation, mulching, plant protection measures etc. Optimum soil moisture level was maintained in the plots through light irrigation as and when required. Observations on morphological characters were recorded on 5 randomly selected plants in each treatment. The data were subjected to statistical analysis following standard procedures (Panse and Sukhatme, 1989).

\section{Results and Discussion}

The significant differences take notice in the growth and fruit physical parameters among the 12 varieties tested are presented in table. The maximal plant height was found variety $\mathrm{V}_{6}$ (Chandler) $14.27 \mathrm{~cm}$ which was statistically at par with varieties $\mathrm{V}_{3}$ (Pajaro) $14.00 \mathrm{~cm}$ and $\mathrm{V}_{9}$ (Dil Pasand) $13.41 \mathrm{~cm}$ also followed variety $\mathrm{V}_{8}$ (No. 5) $12.13 \mathrm{~cm}$, whereas minimal plant height was recoded in variety $\mathrm{V}_{5}$ (Fern) $9.65 \mathrm{~cm}$.In the climatic conditions prevalent at subtropical conditions at Madhya Pradesh, the plants of all the cultivars were observed tall in comparison to plants raised at Bihar (Das et al., 2015). The reason for the variation in these cultivars could be that the genes responsible for the plant height did not express them fully with the same degree as it does at other places because of different agro-climatic conditions. Varietal differences in plant spread and height was also noted by Singh et al., (2008) in Meghalaya which supports the present observation. On observing the Table it was found that the maximum numbers of leaves was observed in the variety $\mathrm{V}_{6}$ (Chandler) 18.07 followed by the varieties $\mathrm{V}_{4}$ (Seascape) 
16.67 and $\mathrm{V}_{5}$ (Fern) 16.40. Although minimum number of leaves per plant was recorded under the variety $\mathrm{V}_{2}$ (Tioga) 13.47. The number of leaves per plant recorded in the present studies was on higher side as reported earlier by Sharma et al., (2014). Variation with respect to number of leaves could be attributed to the fact that different cultivars may react differently to photoperiod, light, temperature, nutrient status of soil, available metabolites and their allocation to the above ground plant parts (Tanaka and Muzuta, 1974). Variety $V_{4} \quad$ (Seascape) regarding maximum number of crowns 2.43. Varieties $\mathrm{V}_{6}$ (Chandler) 2.21 and $\mathrm{V}_{9}$ (Dil Pasand) 2.13, followed by the Variety $V_{4}$ (Seascape) 2.43. Minimum number of crowns was recorded in variety $\mathrm{V}_{7}$ (Shimla Delicious) 1.03.The results are in disagreement with the work of Rahman et al., (2013) obtained a minimum number of crowns per plant in FA 009 (15.33) and FA 006 (14.67) but maximum number of crowns per plant in FA 009 (6.67). The fruit shape of various varieties varied from conic in varieties $V_{3}$ (Pajaro), $\mathrm{V}_{4}$ (Sea scape), $\mathrm{V}_{2}$ (Torrey) and $\mathrm{V}_{12}$ (Sweet Charlie) to long conic in varieties $\mathrm{V}_{1}$ (Northwest), $\mathrm{V}_{9}$ (Dil Pasand) and $\mathrm{V}_{10}$ (Larson). The fruit shape of varieties $\mathrm{V}_{7}$ (Shimla delicious) and $\mathrm{V}_{8}$ (No. 5) was Long wedge while $\mathrm{V}_{6}$ (Chandler) exhibited both conic and long wedge forms varieties $V_{2}$ (Tioga) and $\mathrm{V}_{5}$ (Fern) had necked and long conic fruits shape respectively. The fruit shape of cv. Camarosa was reported to be long wedge, while in Selva it varied from medium conic to flat and wedge. The fruits of Sweet Charlie were similar in shape to those of Selva (Anonymous, 2000). The variation in fruit shape of different varieties may be due to their genetic characters. The maximum fruit length was found in varieties $\mathrm{V}_{10}$ (Larson) $3.80 \mathrm{~cm}$. Varieties $\mathrm{V}_{7}$ (Shimla Delicious) 3.78 $\mathrm{cm}, \mathrm{V}_{4}$ (Seascape) $3.65 \mathrm{~cm}$ and $\mathrm{V}_{6}$ (Chandler) $3.61 \mathrm{~cm}$ were statistically at par with $\mathrm{V}_{10}$ (Larson) $3.80 \mathrm{~cm}$, however the minimum fruit length was recorded in variety $\mathrm{V}_{11}$ (Torrey) $2.82 \mathrm{~cm}$. The variations in the size of the fruit might be due to differential genetic make of the genotypes. This observation finds support from the findings of Dwiwedi et al., (2004). Although maximum fruitbreadth was recorded in variety $\mathrm{V}_{6}$ (Chandler) $2.47 \mathrm{~cm}$ were statistically at par with variety $\mathrm{V}_{11}$ (Torrey) $2.45 \mathrm{~cm}$, followed by varieties $\mathrm{V}_{12}$ (Sweet Charlie) $2.21 \mathrm{~cm}$ and $\mathrm{V}_{10}$ (Larson) $1.94 \mathrm{~cm}$, whereas minimum fruit diameter was observed in variety $\mathrm{V}_{1}$ (Northwest) 1.58 $\mathrm{cm}$. (Lal and Rao 2010) found that fruit diameter of Larsan and Dana was $18.20 \mathrm{~mm}$ and $18.00 \mathrm{~mm}$ respectively which are in agreement with the present work. Kumar et al., (2012) reported the mean value of fruit breadth ranged from $18.78 \mathrm{~mm}$ to $33.93 \mathrm{~mm}$ which is higher than the present investigation. Singh et al., (2012) reported the fruit breadth of Larsan was $16.50 \mathrm{~mm}$ which is in agreement with the present work. The variation in berry breadth may be due to the genetic makeup of the cultivars (Sharma and Sharma, 2006). The maximum fruit weight was attained by the variety $\mathrm{V}_{6}$ (Chandler) 8.58 g. Varieties $V_{12}$ (Sweet Charlie) $7.39 \mathrm{~g}$ were statistically at par and variety $V_{1}$ (Northwest) $7.18 \mathrm{~g}$ followed by the variety $\mathrm{V}_{6}$ (Chandler), whereas the minimum fruit weight was noticed in $\mathrm{V}_{11}$ (Torrey) $5.23 \mathrm{~g}$. The results are in accordance with the work of Kumar et al., (2011), who observed significant variation in days to fruit maturity. This might be due to the excessive vegetative growth, which warranted periodic thinning and pruning of runners. Highest fruit volume was recorded in variety $\mathrm{V}_{6}$ (Chandler) $8.23 \mathrm{ml}$ were statistically at par with varieties $\mathrm{V}_{12}$ (Sweet Charlie) $7.23 \mathrm{ml}, \mathrm{V}_{7}$ (Shimla Delicious) $7.17 \mathrm{ml}$, followed in the variety $\mathrm{V}_{1}$ (Northwest) $6.94 \mathrm{ml}$, whereas lowest fruit volume was observed in variety Torrey (5.41 $\mathrm{ml})$. 
Table.1

\begin{tabular}{|c|c|c|c|c|c|c|c|c|c|c|}
\hline Varieties & $\begin{array}{c}\text { Plant } \\
\text { height } \\
(\mathrm{cm})\end{array}$ & $\begin{array}{c}\text { Number } \\
\text { of } \\
\text { leaves/pl } \\
\text { ant }\end{array}$ & $\begin{array}{l}\text { Number } \\
\text { of } \\
\text { crowns } \\
\text { /plant }\end{array}$ & Fruit shape & $\begin{array}{c}\text { Fruit } \\
\text { length } \\
\text { (cm) }\end{array}$ & $\begin{array}{c}\text { Fruit } \\
\text { diameter } \\
(\mathrm{cm})\end{array}$ & $\begin{array}{c}\text { Fruit } \\
\text { weight (g) }\end{array}$ & $\begin{array}{c}\text { Fruit } \\
\text { volume } \\
\text { (ml) }\end{array}$ & $\begin{array}{l}\text { Specific } \\
\text { gravity }\end{array}$ & $\begin{array}{c}\text { Days taken } \\
\text { to full } \\
\text { maturity } \\
\text { after fruit set }\end{array}$ \\
\hline$V_{1}$ (Northwest) & 10.38 & 14.60 & 1.83 & Long conic & 3.58 & 1.58 & 7.18 & 6.94 & 1.03 & 34.66 \\
\hline$V_{2}$ (Tioga) & 10.36 & 13.47 & 1.61 & $\begin{array}{l}\text { Necked and } \\
\text { Long conic }\end{array}$ & 3.09 & 1.90 & 5.89 & 5.71 & 1.02 & 31.11 \\
\hline$V_{3}$ (Pajero) & 14.00 & 14.80 & 2.02 & Conic & 3.56 & 1.84 & 7.12 & 6.93 & 1.02 & 41.11 \\
\hline$V_{4}$ (Seascape) & 11.85 & 16.67 & 2.43 & Conic & 3.65 & 1.73 & 6.82 & 6.61 & 1.03 & 45.22 \\
\hline$V_{5}($ Fern $)$ & 9.65 & 16.40 & 1.66 & $\begin{array}{l}\text { Necked and } \\
\text { Long conic }\end{array}$ & 3.36 & 1.94 & 6.54 & 6.36 & 1.03 & 35.11 \\
\hline $\mathrm{V}_{6}($ Chandler $)$ & 14.27 & 18.07 & 2.21 & $\begin{array}{l}\text { Conic and } \\
\text { long wedge }\end{array}$ & 3.61 & 2.47 & 8.58 & 8.23 & 1.01 & 39.44 \\
\hline $\begin{array}{l}V_{7} \text { (Shimla } \\
\text { Dalicious) }\end{array}$ & 11.23 & 15.67 & 1.03 & Long wedge & 3.78 & 1.94 & 6.35 & 7.17 & 1.01 & 38.77 \\
\hline $\mathrm{V}_{8}($ No. 5) & 12.13 & 14.93 & 1.83 & Long wedge & 3.42 & 1.89 & 6.19 & 5.64 & 1.03 & 37.55 \\
\hline$V_{9}($ Dil Pasand $)$ & 13.41 & 14.47 & 2.13 & Long conic & 3.35 & 1.80 & 5.89 & 5.73 & 1.02 & 34.55 \\
\hline$V_{10}($ Larson $)$ & 9.95 & 14.07 & 1.80 & Long conic & 3.80 & 1.94 & 6.73 & 6.59 & 1.01 & 36.22 \\
\hline V $_{11}$ (Torrey) & 9.89 & 14.33 & 1.63 & Conic & 2.82 & 2.45 & 5.23 & 5.41 & 1.00 & 38.00 \\
\hline $\begin{array}{l}V_{12} \text { (Sweet } \\
\text { Charlie) }\end{array}$ & 11.21 & 15.43 & 1.43 & Conic & 3.44 & 2.21 & 7.39 & 7.23 & 0.96 & 37.77 \\
\hline S.Em. \pm & 0.24413 & 0.40167 & 0.01601 & & 0.08379 & 0.03225 & 0.42117 & 0.38119 & 0.01159 & 0.51508 \\
\hline CD at $5 \%$ & 0.71602 & 1.17806 & 0.04695 & & 0.24575 & 0.09457 & 1.23526 & 1.11799 & 0.03399 & 1.51068 \\
\hline CV (\%) & 3.66828 & 4.56454 & 1.53934 & & 4.2006 & 2.82954 & 10.9538 & 10.0839 & 1.97952 & 2.38166 \\
\hline
\end{tabular}


It was observed that the specific gravity of the varieties have negligible difference aspect the variety $\mathrm{V}_{12}$ (Sweet Charlie) 0.96. Although the maximum specific gravity was recorded in variety $\mathrm{V}_{4}$ (Seascape) 1.03 and minimum specific gravity was recorded in the variety $\mathrm{V}_{12}$ (Sweet Charlie) 0.96. There is negligible difference in specific gravity by this might be due to different time of fruit maturity and environment conditions. Minimum days for fruit maturity was taken by variety $\mathrm{V}_{2}$ (Tioga) 31.11 days, whereas variety $\mathrm{V}_{4}$ (Seascape) the taken maximum days 45.22 and next early fruit maturating varieties $V_{9}$ (Dil Pasand) 34.55 days, $V_{1}$ (Northwest) 34.66 days and $V_{5}$ (Fern) 35.11 days for fruit maturity.

On the basis of results, it is concluded that out of 12 strawberry varieties, the variety $V_{6}$ (Chandler) resulted best in growth and fruit physical parameters plant height, number of leaves, fruit diameter, fruit weight, fruit volume. Variety $\mathrm{V}_{12}$ (Larson) observed for maximum fruit length and highest number of crowns was recorded in variety $\mathrm{V}_{4}$ (Seascape). The noticed earliest fruit maturity after fruit set variety $V_{2}$ (Tioga) and specific gravity was best found in variety $\mathrm{V}_{11}$ (Torrey).

\section{References}

Anonymous (2000). Strawberry shapes. http//www.strawberry.ifas.ufl.edu.

Das, A.K.; Singh, K.P.; Prasad, B. and Kumar, R. (2015). Evaluation of cultivars of strawberry, a temperate fruit for its adaptability as well as productivity in sub-tropical agroclimatic condition of Supaul district in Bihar. The Asian Journal of Horticulture. 10(2): 278-28.

Dwivedi, S. K.; Abdule, K. and Raut, B. 2004. Introduction and evaluation of strawberry cultivars for cold arid conditions of Ladakh. Progressive Horticulture. 36(2): 207-10.
Kumar, R. (2002).Studies on the performance of some strawberry (Fragaria $x$ ananassa L.) cultivars. M.Sc. (Ag) Thesis, Indira Gandhi Krishi Vishwavidyalaya, Raipur. pp. 27- 64.

Kumar, A. and Ahad, I. (2012). Growth, yield and fruit quality of strawberry under protected cultivation in South Kashmir. Adv. Hort. Sci., 26(2): 88-91.

Kumar, A. and Kumar, P. (2011). Studies on vegetative growth, yield and quality attributes of strawberry under temperate agro-climatic zone conditions of Kashmir valley. Haryana J. Hort. Sci. 40(1\&2): $10-12$.

Lal, B. and Rao, B. K. (2010).Physicochemical characteristics of some strawberry (Fragaria $\times$ ananassa) genotypes under Garhwal region of Uttarakhand. Indian Journal of Agricultural Sciences. 80(4): 342-4.

Panse, V. G. and Sukhatme, P. V. (1995) Statistical methods for agricultural workers. New Delhi: ICAR Publication.

Rahman, M.M.; Rahman, M.M.; Hossain, M.M.; Main, K.M.A. and Khaliq, A.l.Q. (2013).Characterization and field performance of 15 strawberry germplasm under Bangladesh conditions. J. Agri. 11(2): 81-94.

Sharma G and Sharma O C. 2006.Correlation and path analysis in strawberry (Fragaria $\times$ ananassa Duch).The Horticulture Journal.19: 1-4.

Sharma, G.; Yadav, A. and Thakur, M. (2014).Studies on Growth and Flowering Attributes of Different Strawberry Cultivars (Fragaria $x$ ananassa Duch.) in Himachal Pradesh. Asian J. of Adv. Basic Sci. 3(1): 1-4.

Shamaila, M., Baumann, T. E., Eaton, G. W., Powrie, W.D. and Skura, B. J. (1992). Quality attributes of strawberry cultivars grown in British Columbia. $J$. Food Sci., 57(3): 696-99.

Singh, A. and Patel, R.K. (2008).Performance 
of strawberry cultivars under subtropics of Meghalaya. Indian Journal of Agricultural Sciences 78(7): 575-580.

Singh, S.R.; Srivastava, K.K.; Sharma, M.K.; Singh, L. and Sharma V.K. (2012).Screening of strawberry (Fragaria $\times$ ananassa Duch.) varieties under organic production system for Kashmir valley. Indian Journal of
Agricultural Sciences.82(6): 538-542. Tanaka, Y. and Mizuta, M. (1974). Nutritional-physiological studies on strawberry cv. Hokowase in long term cultivation. In: Influence of nitrogen on growth, yield and absorption of nutrients. Bull. Nara. Agric. Expt. Sta. 6: $38-43$.

\section{How to cite this article:}

Umesh Kumar, Priyamvada Sonkar and Pankaj Maida. 2020. Performance of Strawberry (Fragaria $x$ ananassa Duch.) Varieties for Growth and Fruit Physical Parameters under Western Malwa Plateau Conditions of Madhya Pradesh, India. Int.J.Curr.Microbiol.App.Sci. 9(01): 1347-1352. doi: https://doi.org/10.20546/ijcmas.2020.901.149 